\section{Molecular Markers Associated with Morphological Traits in Watermelon}

\author{
Leigh K. Hawkins and Fenny Dane \\ Auburn University, Department of Horticulture, 101 Funchess Hall, Auburn, \\ AL 36849
}

Thomas L. Kubisiak

USDA Forest Service, Southern Institute for Forest Genetics, 23332 Highway 67, Saucier, $M S$

Additional index words. C. lanatus var. lanatus, C. lanatus var. citroides, random amplified polymorphic DNA, RAPD

\begin{abstract}
Morphological traits were examined in an $\mathrm{F}_{3}$ generation derived from a cross between $C$. lanatus var. lanatus [(Thunb.) Matsum. \& Nakai] and $C$. lanatus var. citroides. At least three genes, $C$ (yellow) vs. $c$ (red), $i$ (inhibitory to $C$ ) vs. $I$ (noninhibitory to $C$ ), and $y$ (yellow) vs. $y_{w}$ (white), with epistatic and inhibitory actions were found to govern the inheritance of fruit flesh color. The high frequency of yellow-fleshed fruit and low frequencies of white and red fruits can be explained by the presence of a new allele $\left(y_{w}\right.$ recessive to $\left.y\right)$ in the multiple allele series at the $Y$ locus. The low frequency of tan colored seeds in segregating populations could be explained by at least three genes governing inheritance of seed-coat color. Single factor analysis of variance was conducted for each pairwise combination of random amplified polymorphic DNA (RAPD) locus and fruit or seed characteristics. Several RAPD loci were identified to be loosely linked to morphological characteristics.
\end{abstract}

Variations in morphological characteristics among cultivated watermelons [Citrullus lanatus var. lanatus, $2 n=2 \mathrm{x}=22]$ are relatively low (Biles et al., 1989; Hashizume et al., 1996), while the cultivated and wild form (C. lanatus var. citroides) differ in fruit and seed characteristics, and important disease resistance genes. Within the species, fruits range from small, hard, bitter, white, and inedible to large, succulent, red or yellow, and sweet (Chakravarty, 1990; Lee et al., 1996; Robinson and Decker-Walters, 1997). Some of the morphological characteristics most well studied in watermelon are fruit flesh color (Poole, 1944; Henderson, 1989; Henderson et al., 1998), flower color (Kwon and Dane, 1999), seed characteristics (Porter, 1937; Poole et al., 1941), bitterness (Chambliss et al., 1968; Navot et al., 1990), and fruit weight and shape (Poole, 1945).

The Mendelian inheritance of some traits in watermelon has been demonstrated (Table 1). The action of several genes govern fruit flesh color. Shimotsuma (1963) reported a two-gene model [ $W f$ (white) and $b$ (yellow)] controlling flesh color in an interspecific Citrullus cross. A white fleshed $\mathrm{F}_{1}$ and a ratio of 12 white, 3 yellow, and 1 red in the $F_{2}$ indicated epistatic interaction between $W f$ and $b$. Hashizume et al. (1996) in a cross between a cultivated red-fleshed watermelon and a white-fleshed wild African form observed a yellow fleshed $F_{1}$ and backcross $\left(\mathrm{BC}_{1}\right)$ population with fruit color segregation of 1 yellow : 1 white. Henderson et al. (1998) detected three genes involved in the inheritance of flesh color of cultivated watermelon

Received for publication 6 Nov. 2000. Accepted for publication 20 Mar. 2001. varieties: $C$ (yellow) vs. $c$ (red); a multiple allelic series $Y$ (red flesh) dominant to $y^{o}$ (orange) and dominant to $y$ (pale yellow); and $i$ (inhibitor to $C$ ) vs. $I$ (non-inhibitory to $C$ ) (Table 1). The $C$ locus is epistatic to the $Y$, such that $C-Y-, C-y y$, and ccyy give yellow fruit flesh and $c c Y$-results in red flesh. Fruit shape (width : length ratio) is reportedly controlled by a pair of codominant alleles (Poole, 1945).

Seed coat color in watermelon ranges from almost pure white through red, green, tan, mahogany, and black in various superimposed complex patterns (Poole et al., 1941). Kanda (1931) reported on interactions of at least seven pairs of genes that govern appearance of the seeds with black dominant to all colors and patterns. Poole et al. (1941) proposed a three-gene model $(r, t, w)$ and a specific modifier $(d)$ for degree of blackness for the inheritance of seed coat colors and patterns in watermelon. El-Hafez et al. (1981; 1985) described that cracks on the seed coat genes $\left(c_{r}\right)$.

Watermelon suffers from a number of serious fungal, bacterial, and viral diseases that reduce yield and quality (Robinson and Decker-Walters, 1997). Fusarium wilt, caused by the soilborne fungus Fusarium oxysporum f. sp. niveum (FON), is one of the most economically important diseases of watermelon. While genetic linkage maps have been created using molecular, morphological, and disease resistance markers in intraspecific cucumber (Cucumis sativus L.) (Kennard et al., 1994; Meglic and Staub, 1996), and in intra- and interspecific melon (Cucumis melo L.) populations (Danin-Poleg et al., 1998; Oliver et al., 1998), genome mapping in wawere under the control of a single pair of termelon is still in its infancy. Development of a molecular marker linkage map makes it possible to locate and manipulate individual genetic factors associated with complex traits (Jung et al., 1996; Liu, 1997). Defining the genetic control of these traits will assist breeders and subsequent molecular mapping will contribute to the development of markerassisted selection (Perin et al., 1998; Staub et al., 1996). A random amplified polymorphic DNA (RAPD)-based map was developed in a watermelon population segregating for Fusarium wilt resistance (Hawkins et al., 2001). The objectives of this research were to determine linkages among several morphological traits and RAPD markers in the same mapping population and if possible, determine genomic regions controlling watermelon fruit and seed characteristics.

\section{Materials and Methods}

Plant material. The watermelon cultivar 'New Hampshire Midget' (NHM) (C. lanatus var. lanatus) and the plant introduction $C$. lanatus var. citroides PI 296341 were chosen because of their differing levels of resistance to Fusarium wilt (Hawkins et al., 2001). NHM, an early variety with small round fruit, red flesh, and light green rind color, is susceptible to races 1, and 2 of FON (Zhang and Rhodes, 1993), while PI 296341, a primitive watermelon with small round fruit and white flesh, has resistance to all races of FON (Martyn and Netzer, 1991). The $\mathrm{F}_{1}$ and individual $\mathrm{F}_{2}$ plants were selfed to create $\mathrm{F}_{3}$ families.

Morphological trait analysis. In Summer 1998, PI 296341, NHM, $\mathrm{F}_{1}$, and $72 \mathrm{~F}_{3}$ families (eight plants per family) were grown at the Auburn Univ. E.V. Smith Research Station in Shorter, Ala. The experimental plots consisted of 105-m rows, pre-treated with methyl bromide, with 0.9 m between hills in a completely randomized design. One control group, containing PI 296341, $\mathrm{F}_{1}$, and NHM plants, and six $\mathrm{F}_{3}$ families was randomly planted per row. 'AU-Producer' was planted in the border rows.

Four open-pollinated fruits were harvested per $\mathrm{F}_{3}$ family and evaluated for 10 morphological traits: fruit weight $(\mathrm{g})$, length, and width $(\mathrm{cm})$, shape; soluble solids; seed coat color and pattern; seed length and width $(\mathrm{mm})$; and fruit flesh color. The percentage of soluble solids or brix levels were evaluated using a handheld refractometer (model Brix 30; Kernco Instruments Co., El Paso, Texas). Flesh color was determined using a color chart from the Royal Horticultural Society, London, in association with the Flower Council of Leiden, Holland. For each $\mathrm{F}_{2}$ and $\mathrm{F}_{3}$ family, 24 seeds were evaluated as black, black/slashed, stippled, or tan. Fruit shape was based on the width : length ratio (Poole, 1945).

DNA isolation. DNA was extracted using a modified CTAB extraction technique (Wagner et al., 1987) with additional purification steps (Kubisiak et al., 1997), or using the Phytopure plant DNA extraction kit 
Table 1. Genes identified for morphological characteristics in watermelon.

\begin{tabular}{|c|c|c|}
\hline Gene symbol & Trait and description & Reference \\
\hline \multicolumn{3}{|c|}{ Fruit characteristics } \\
\hline$S u$ or $B i$ or $s u^{B i}$ & Suppressor of bitterness, non-bitter fruit. Bitterness in C. colocynthis is due to $S u S u$ genotype. & $\begin{array}{l}\text { Chambliss et al. } 1968 \text {; } \\
\text { Navot et al. } 1990\end{array}$ \\
\hline$O$ & Elongate fruit $(O)$ dominant to spherical fruit $(o)$. & Weetman, 1931 \\
\hline \multicolumn{3}{|c|}{ Flesh color } \\
\hline$W f$ & $\begin{array}{l}\text { White flesh. Wf is epistatic to the } 2^{\text {nd }} b \text { (or } C \text { ) that conditions yellow (Canary yellow and red flesh). } \\
W f-B \text { - and } W f-b b=\text { white flesh, } w f w f B-=\text { yellow, } w f w f b b=\text { red. }\end{array}$ & Shimotsuma, 1963 \\
\hline$C$ & Canary yellow flesh, dominant to pink. & Poole, 1944 \\
\hline$y$ or $r$ & Yellow flesh ('Golden Honey' type), recessive to Y (red flesh). & Shimotsuma, 1963 \\
\hline$y^{o}$ & $\begin{array}{l}\text { Orange flesh (from 'Tendersweet Orange Flesh'), allelic to } y . Y \text { (red flesh) is dominant to } y^{o} \\
\text { and } y \text { (yellow flesh). } y^{o} \text { is dominant to } y \text {. }\end{array}$ & $\begin{array}{l}\text { Henderson et al., 1989; } \\
\text { Poole, 1944; Porter, } 1937\end{array}$ \\
\hline$i$ & Inhibitor of $C$ (Canary yellow flesh), recessive to $I$ (non-inhibitory to $C$ ). & Henderson et al., 1989 \\
\hline \multicolumn{3}{|c|}{ Seed characteristics } \\
\hline$l$ & Long seed. Long $(11.5-16.5 \mathrm{~mm})$ recessive to medium $(7.5-11.5 \mathrm{~mm})$. & Poole et al., 1941 \\
\hline$s$ & Short seed $(4.5-7.5 \mathrm{~mm})$ epistatic to long seed & Poole et al., 1941 \\
\hline$r$ & Red seed coat, interacts with $w$ and $t, r t W=$ red. & Poole et al., 1941 \\
\hline$t$ & Tan seed coat, interacts with $r$ and $t, R t W=\tan$ & Poole et al., 1941 \\
\hline$w$ & White seed coat, interacts with $r$ and $w, r t w=$ white, $R T W=$ black, $R t w=$ white tan-tipped. & Poole et al., 1941 \\
\hline$d$ & Dotted seed coat. Black dotted seeds are dominant for $r, t$, and $w . R T W D=$ black. & $\begin{array}{l}\text { Kanda, 1931; Poole et al., 1941; } \\
\quad \text { Poole, } 1945\end{array}$ \\
\hline $\mathrm{cr}$ & $\mathrm{Cr}$ (non-cracked) vs. $\mathrm{cr}$ (cracked). & El-Hafez et al., 1981, 1985 \\
\hline
\end{tabular}

(Amersham Pharmacia Biotech, Piscataway, N.J.). DNA was isolated from 0.5 grams of fresh cotyledon tissue from two-week-old Fusarium wilt resistant, susceptible, $F_{1}$, and leaf tissue of at least four individuals from each $\mathrm{F}_{3}$ family (Hawkins et al., 2001). The tissue was ground in liquid nitrogen and either immediately used for DNA extraction or stored at $-80{ }^{\circ} \mathrm{C}$. The extracted DNA was suspended in TE buffer and quantified using a Hoefer DyNA Quant $200^{\mathrm{TM}}$ fluorometer (Hoefer Pharmacia Biotech, San Francisco). The DNA concentration was adjusted as required for a given application and stored at $20{ }^{\circ} \mathrm{C}$ until needed.

$R A P D$ analysis. One hundred-eighteen decamer RAPD primers from Operon Technologies (OP; Alameda, Calif.) and the Univ. of British Columbia (UBC; Vancouver, BC Canada), along with five 12-mer RAPD primers identified by Hashizume et al. (1993; 1996) were screened for their ability to detect polymorphisms between NHM and PI 296341. Selected primers were used to amplify polymorphic bands in four individuals from $28 \mathrm{~F}$ families selected for their response to the Fusarium wilt pathogen (Hawkins et al., 2001).

PCR was performed in a $25-\mu \mathrm{L}$ volume containing $10 \mathrm{~mm}$ Tris- $\mathrm{HCl}, 3.0 \mathrm{~mm} \mathrm{MgCl}_{2}$, $10 \mathrm{~mm} \mathrm{KCl}$ (pH 8.3), $0.2 \mathrm{~mm}$ of each nucleotide (Perkin Elmer, Branchburg, N.J.), 5 $\mu$ mol decamer or $12 \mathrm{mer}$ oligonucleotide primers, $10 \mathrm{ng}$ genomic DNA and 1 unit of Amplitaq polymerase (Perkin Elmer, Branchburg, N.J.). The thermocyclers were programmed as follows: initial denaturation at $94^{\circ} \mathrm{C}$ for $10 \mathrm{~min}, 35$ cycles of $94^{\circ} \mathrm{C}$ for $45 \mathrm{~s}$, $36{ }^{\circ} \mathrm{C}$ for $45 \mathrm{~s}$, and $72{ }^{\circ} \mathrm{C}$ for $2 \mathrm{~min}$, followed by a final extension at $72{ }^{\circ} \mathrm{C}$ for $5 \mathrm{~min}$. Amplification products were electrophoresed on $1.2 \%$ agarose gels and detected by staining with ethidium bromide. The gels were photographed under UV light with Polaroid film 667. Lambda DNA digested with PstI was used as a molecular size marker. Each band was named by the primer used and its size in basepairs (bp's), such that OPF16 1600 is the $1600 \mathrm{bp}$ band amplified by Operon primer F16.

Statistical analysis. Data from four individuals in $28 \mathrm{~F}_{3}$ families were analyzed based on single factor ANOVA for each pairwise combination of marker loci and quantitative trait (SAS Institute, 1996). F tests $(P<0.05)$ were used to determine if significant differences in trait expression were associated with differences in marker locus-genotypic classes (Edwards et al., 1987). Heritability estimates were calculated for percentage of soluble solids, fruit weight, seed length and width, and fruit weight, length, width, and shape. Heritability was calculated using the following formula:

$$
\mathrm{h}^{2}=\sigma_{\mathrm{g}}^{2} / \sigma_{\mathrm{g}}^{2}+\sigma_{\mathrm{e}}^{2}, \sigma_{\mathrm{g}}^{2}=\left(\mathrm{MS}_{\mathrm{g}}-\mathrm{MS}_{\mathrm{e}}\right) / \mathrm{k} \text {, }
$$

where $\mathrm{k}=$ number of replications and $\sigma_{\mathrm{e}}^{2}=\mathrm{MS}_{\mathrm{e}}$ (residual) (Liu, 1997).

\section{Results and Discussion}

Seed characteristics. Seeds from NHM are on average $1.1 \times 0.7 \mathrm{~cm}$, dark brown to black in color, while PI 296341 seeds are on average $1.0 \times 0.6 \mathrm{~cm}$, reddish-brown, stippled, with a few cracks on the seed coat. $F_{1}$ seeds are dark brown with some tan cracks and range in size from 1.0 to $1.1 \times 0.6$ to $0.7 \mathrm{~cm}$. Seed lengths in $\mathrm{F}_{2}$ and $\mathrm{F}_{3}$ progeny varied from 0.7 to $1.3 \mathrm{~cm}$, seed widths from 0.4 to $0.9 \mathrm{~cm}$ (Fig. 1, A and B). In the $\mathrm{F}_{2}$ generation, a wide variety of seed patterns was observed, including the tan, red and clump, and stippled characteristics described by Poole et al. (1941). When seeds from the $F_{2}$ were scored as black vs. nonblack, $50 \mathrm{~F}_{2}$ plants produced black seeds, 19 nonblack, resulting in good fit to a 3:1 segregation ratio $\left(\chi^{2}=0.24, \mathrm{df}=1\right)$. Similarly, when the seeds were scored as non-stippled vs. stippled, $53 \mathrm{~F}_{2}$ plants had nonstippled seed vs. 16 stippled, which fit a ratio of 3 nonstippled vs. 1 stippled $\left(\chi^{2}=\right.$ $0.12, \mathrm{df}=1)$. The low frequency of tan seeds ( $3 \%$ in the $\mathrm{F}_{2}$ and $4 \%$ in the $\mathrm{F}_{3}$ generation), a recessive trait, can be explained by the interactions of at least three genes that govern the inheritance of seed color in this population. The frequency of black-seeded phenotypes and stippled seeded phenotypes increased from the $\mathrm{F}_{2}$ ( $43 \%$ black, $12 \%$ stippled) to the $\mathrm{F}_{3}\left(55 \%\right.$ black, $40 \%$ stippled). In the $\mathrm{F}_{3}$ generation, seeds had a more uniform appearance among the families, but showed more differences in pattern within the family. One trait, cracked seed coat, was noticeably absent. This trait was examined by El-Hafez et al. $(1981 ; 1985)$ and found to be controlled by a recessive gene $\left(c_{r}\right)$. Cracked seeds were observed on PI 296341, $F_{1}$ and several $F_{2}$ seeds, but seldom appeared in the $\mathrm{F}_{3}$, which points toward epistatic interactions between loci involved in the inheritance of seed-coat colors. Phenotypes of watermelon seed-coat colors are difficult to classify because of variable degrees of expression. Since this trait is under multigenic control, advanced generations, such as recombinant inbred lines, in addition to reciprocal backcrosses are needed to further deduce its complex inheritance. The elucidation of the inheritance of seed-coat color has also proved problematic in other plant species. Using $80 \mathrm{~F}_{2}$ individuals, Kaga et al. (1996) were unable to clarify the mechanism of seed color expression in azuki bean because of complicated segregation patterns.

Fruit characteristics. Individual $\mathrm{F}_{3}$ fruit weights ranged from $0.4 \mathrm{~kg}$ to $4.5 \mathrm{~kg}$, fruit lengths varied from 10 to $23.4 \mathrm{~cm}$, while fruit widths ranged from 4.3 to $21.3 \mathrm{~cm}$, and their soluble solids ranged from $3 \%$ to $7 \%$ (Figure 1 C, D, E, and F). Fruits of PI 296341 were white (155A from the RHS color chart), NHM red, and the $F_{1}$ yellow ( $8 \mathrm{C}$ ). Thirty nine of the $\mathrm{F}_{3}$ lines produced yellow fruits only, four red only, four white only, 17 segregated as yellow and white, five segregated as yellow and red, one segregated red and white, and one segregated red, yellow and white. In some fruit, the color red was found localized to areas around the seeds. The presence of yel- 

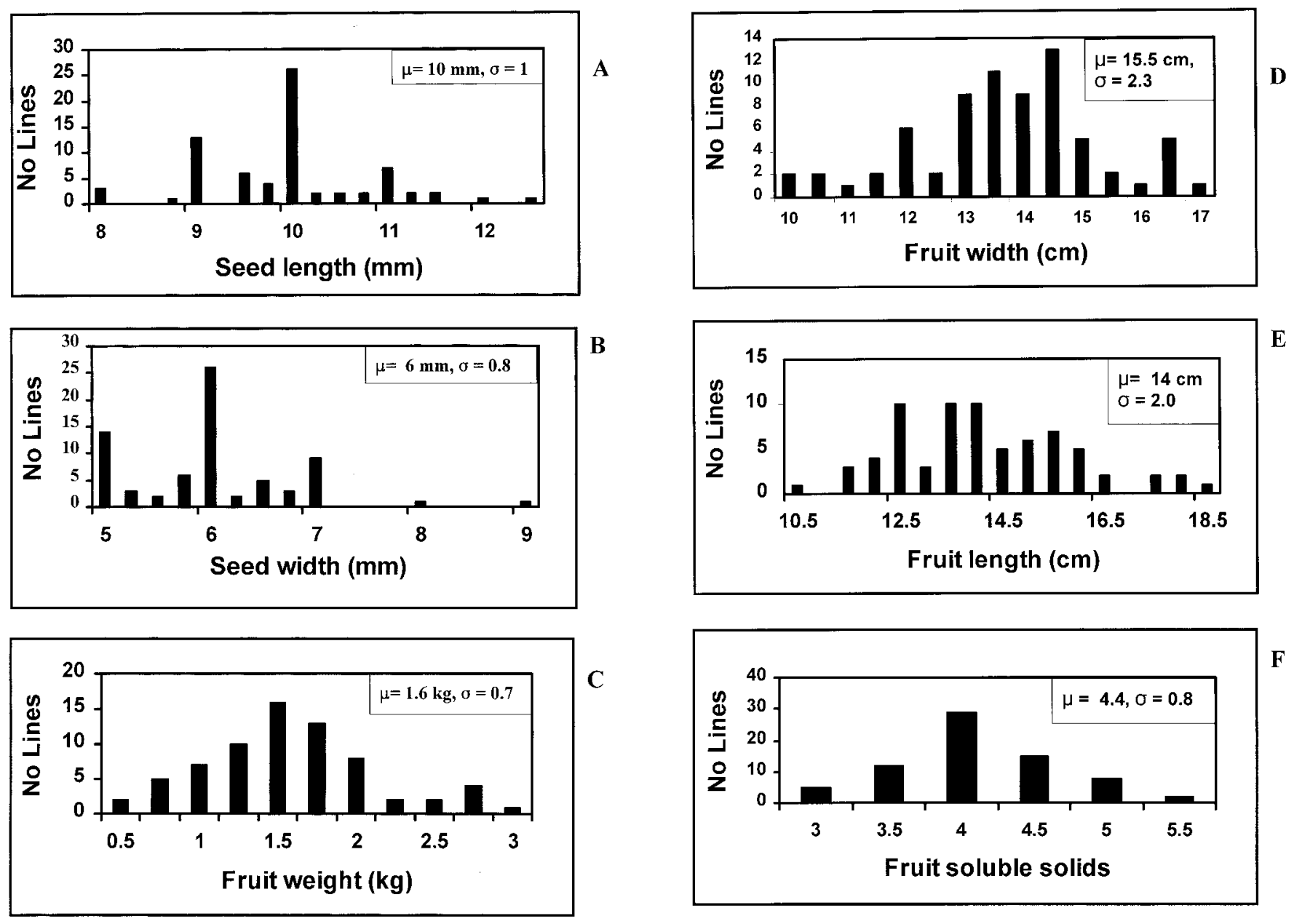

Fig. 1. Frequency distribution of fruit characteristics in $F_{3}$ lines derived from a cross between the Fusarium wilt-susceptible NHM and resistant PI 296341. A $=$ seed length, $\mathrm{B}=$ seed width, $\mathrm{C}=$ fruit weight, $\mathrm{D}=$ fruit length, $\mathrm{E}=$ fruit width and $\mathrm{F}=$ soluble solids.

low fruit in the $F_{1}$ and high incidence of yellow fruit in the $\mathrm{F}_{3}$ generation indicates that yellow is dominant over white and red.

Henderson et al. (1998) suggested that at least three genes control the inheritance of fruit flesh color. In addition to the genes $C$ (yellow) vs. $c$ (red) and $i$ (inhibitory to $C$ ) vs. $I$ (noninhibitory to $C$ ), described by Henderson et al. (1998), it is proposed that a new allele be added to the multiple allelic sequence of $Y$. This gene is designated $y_{w}$, conditions white flesh, and is recessive to $y$ (canary yellow flesh). The $C$ locus is epistatic to $y$, such that $C-y-, C-y_{w} y_{w}, c c y_{w} y_{w}$ are yellow-fleshed, and $c c y$ - is red-fleshed. White-fleshed fruits occur when the $i$ locus inhibits the $C$ locus in the presence of $y_{w} y_{w}$ (Table 2). The proposed parental genotypes are IIccyy (red) for New Hampshire Midget, $i i C C y_{w} y_{w}$ (white) for PI 296341 and $I i C c y y_{w}$ (yellow) for the $\mathrm{F}_{1}$. In 17 $\mathrm{F}_{3}$ lines yellow and white fruit were detected (possible $\mathrm{F}_{2}$ genotypes : I-C- $y_{w} y_{w}, I-c c y_{w} y_{w}$, ii $C$ - $y$-, iiccy-), five $\mathrm{F}_{3}$ lines produced yellow and red fruit (I-ccyy, IIC-y-, IIC-yy), one $\mathrm{F}_{3}$ line produced yellow, white and red fruit $(I-$ $c c y$ - or I-C-y-) and one $\mathrm{F}_{3}$ line produced red and white fruit (I-ccy-). A total of 41 red and 45 white fruit were observed in the $F_{3}$, which resulted in a good fit to the expected segregation ratio of 365 yellow : 75 red : 72 white $\left(\chi^{2}=0.75, P<0.05, \mathrm{df}=2\right.$; Table 2$)$. The proposed theory of three loci with epistatic and inhibitory actions governing the inheritance of fruit color in this population accounts for the large number of yellow-fleshed fruits and the scarcity of red and whitefleshed fruits in the $\mathrm{F}_{3}$.

$R A P D$ analysis. Those primers that did not provide a reproducible amplification product or were monomorphic, were excluded from this investigation. RAPD loci exhibiting the expected 5 presence : $3 \mathrm{ab}$ sence Mendelian segregation ratio in the $\mathrm{F}_{3}$ were compared against each morphological trait using single factor analysis of variance (ANOVA) (Table 3). Several RAPD marker loci were found to be linked to fruit color, fruit length, soluble solids, fruit width, seed length, fruit weight, and seed color (Table 3). The heritability of fruit width, fruit length, fruit weight, seed length, seed width, and soluble solids was calculated and ranged from 0.33 for seed length, 0.38 for fruit shape, 0.39 for soluble solids, 0.40 for fruit weight, 0.47 for fruit width, 0.49 for fruit length, 0.50 for seed width. Most of the RAPD loci and consequently the quantitative trait loci (QTLs) governing the morphological characteristics could not be assigned to specific genomic regions. Only seed length and width could be assigned to linkage group 3 . The low heritability estimates detected for the various morphological characteristics (Fig. 1) and the dominant nature of the molecular marker hindered identification of RAPD loci linked to the traits. QTLs affecting cucumber fruit shape (length : diameter ratio) were identified by Dijkhuizen and Staub (1999). Differences in QTL number and location could be attributed to disparities in population size, dominance, and the amount of genotypic information available. Fruit length, diameter, and to a lesser extent shape are developmentally dependent, and thus map placement of QTL was affected by the physiological stage of fruit development (Dijkhuizen and Staub, 1999). Only through the development of a more detailed linkage map of the watermelon genome, will it be possible to precisely assign QTLs for the various morphological characteristics to specific genomic regions.

\section{Literature Cited}

Biles, C.L., R.D. Martyn, and H.D. Wilson. 1989 Isozymes and general proteins from various watermelon cultivars and tissue types. HortScience 24:810-812.

Chakravarty, H.L. 1990. Cucurbits of India and 
Table 2: Proposed genotypes and phenotypes for fruit flesh color observed in $\mathrm{F}_{3}$ watermelon population derived from a cross between the Fusarium wilt-susceptible NHM (IIccyy) $\mathrm{x}$ the Fusarium-wilt resistant PI $296341\left(\right.$ iiCC $\left.y_{w} y_{w}\right)$.

\begin{tabular}{lcccc}
\hline $\begin{array}{l}\text { Proposed } \\
\text { genotypes }\end{array}$ & $\begin{array}{c}\text { Expected } \\
\text { phenotypes }\end{array}$ & $\begin{array}{c}\text { Expected } \mathrm{F}_{3} \text { family } \\
\text { phenotypic segregation ratio }\end{array}$ & $\begin{array}{c}\text { Expected } \\
\mathrm{F}_{3} \text { phenotypes }\end{array}$ & $\begin{array}{c}\text { Observed } \\
\mathrm{F}_{3} \text { phenotypes }\end{array}$ \\
\hline I-C-y- & yellow & $27(\mathrm{Y}: \mathrm{R}: \mathrm{W}=51: 9: 4)^{\mathrm{z}}$ & 125 & 196 yellow \\
$\mathrm{I}-\mathrm{C}-\mathrm{y}_{\mathrm{w}} \mathrm{y}_{\mathrm{w}}$ & yellow & $9(\mathrm{Y}: \mathrm{W}=3: 1)$ & 75 & 41 red \\
$\mathrm{I}-\mathrm{ccy}-$ & red & $9(\mathrm{Y}: \mathrm{R}: \mathrm{W}=6: 9: 1)$ & 75 & 45 \\
$\mathrm{I}-\mathrm{ccy} \mathrm{y}_{\mathrm{w}}$ & yellow & $3(\mathrm{Y}: \mathrm{W}=3: 1)$ & 75 & 45 white \\
iiC-y- & yellow & $9(\mathrm{Y}: \mathrm{W}=3: 1)$ & 45 & \\
iiC- $\mathrm{y}_{\mathrm{w}} \mathrm{y}_{\mathrm{w}}$ & white & 3 white only & 45 & 27 \\
iiccy- & yellow & $3(\mathrm{Y}: \mathrm{W}=3: 1)$ & & $0.75(\mathrm{df}=2)$ \\
iicc $\mathrm{y}_{\mathrm{w}} \mathrm{y}_{\mathrm{w}}$ & white & 1 white only & & \\
$\chi^{2}$ & & & &
\end{tabular}

${ }^{\mathrm{z}} \mathrm{Y}=$ yellow, $\mathrm{R}=$ red, $\mathrm{W}=$ white.

Table 3. Single factor ANOVA of molecular marker and phenotypic data in $\mathrm{F}_{3}$ watermelon lines derived from a cross between fusarium wilt susceptible NHM and resistant PI 296341.

\begin{tabular}{|c|c|c|c|c|}
\hline \multirow[b]{2}{*}{ Trait } & \multirow{2}{*}{$\begin{array}{l}\text { RAPD } \\
\text { marker }\end{array}$} & \multicolumn{2}{|c|}{ Single factor ANOVA } & \multirow{2}{*}{$\begin{array}{c}\text { Linkage } \\
\text { group }\end{array}$} \\
\hline & & $P>\mathrm{F}^{\mathrm{z}}$ & $R^{2 \mathrm{y}}$ & \\
\hline \multirow[t]{3}{*}{ Seed length } & $\mathrm{B} 15_{1700}$ & 0.020 & 6.5 & $\mathrm{U}^{\mathrm{x}}$ \\
\hline & $\mathrm{W} 04_{1700}$ & 0.033 & 5.1 & $\mathrm{U}$ \\
\hline & $\mathrm{X} 13_{805}$ & 0.024 & 5.2 & 3 \\
\hline \multirow[t]{3}{*}{ Seed width } & W09 & 0.017 & 13.5 & 3 \\
\hline & $\mathrm{X} 13_{1093}$ & 0.028 & 4.9 & $\mathrm{U}$ \\
\hline & $\mathrm{X} 13_{805}$ & 0.036 & 4.4 & 3 \\
\hline \multirow[t]{3}{*}{ Seed color } & $\mathrm{L}_{1} 1_{750}$ & 0.025 & 5.1 & $\mathrm{U}$ \\
\hline & $\mathrm{Y} 15_{1093}$ & 0.025 & 5.3 & $\mathrm{U}$ \\
\hline & $\mathrm{M} 17_{468}$ & 0.029 & 5.6 & 4 \\
\hline \multirow[t]{4}{*}{ Fruit length } & $\mathrm{F} 04_{805}^{400}$ & 0.013 & 6.7 & $\mathrm{U}$ \\
\hline & $\mathrm{K} 14_{1093}$ & 0.017 & 8.0 & $\mathrm{U}$ \\
\hline & $\mathrm{K} 14_{900}$ & 0.030 & 6.2 & $\mathrm{U}$ \\
\hline & $\mathrm{C} 16_{480}$ & 0.002 & 11.9 & $\mathrm{U}$ \\
\hline \multirow[t]{2}{*}{ Fruit width } & $\mathrm{B} 12_{468}$ & 0.015 & 5.3 & $\mathrm{U}$ \\
\hline & $\mathrm{C} 16_{480}$ & 0.016 & 7.5 & $\mathrm{U}$ \\
\hline \multirow[t]{4}{*}{ Fruit shape } & W19 1093 & 0.042 & 5.3 & $\mathrm{U}$ \\
\hline & $\mathrm{X} 13_{1093}$ & 0.009 & 7.2 & $\mathrm{U}$ \\
\hline & $\mathrm{K} 14_{1093}$ & 0.003 & 11.8 & $\mathrm{U}$ \\
\hline & $\mathrm{K} 14_{900}$ & 0.012 & 8.1 & $\mathrm{U}$ \\
\hline \multirow[t]{2}{*}{ Fruit weight } & B 12 & 0.039 & 4.5 & $\mathrm{U}$ \\
\hline & $\mathrm{C} 16_{480}$ & 0.007 & 9.3 & $\mathrm{U}$ \\
\hline \multirow[t]{7}{*}{ Fruit color } & $\mathrm{C} 12_{470}$ & 0.029 & 5.4 & $\mathrm{U}$ \\
\hline & $\mathrm{F} 04_{805}$ & 0.046 & 4.3 & 5 \\
\hline & $\mathrm{L}_{11} 1_{750}$ & 0.011 & 6.4 & $\mathrm{U}$ \\
\hline & $\mathrm{Y} 14_{468}$ & 0.016 & 7.0 & $\mathrm{U}$ \\
\hline & $\mathrm{W} 02_{1180}$ & 0.014 & 6.9 & $\mathrm{U}$ \\
\hline & Y15 1093 & 0.025 & 5.3 & $\mathrm{U}$ \\
\hline & $\mathrm{M}_{17} 7_{468}$ & 0.029 & 5.6 & 4 \\
\hline Soluble solids & $\mathrm{C} 16_{480}$ & 0.005 & 10.1 & $\mathrm{U}$ \\
\hline
\end{tabular}

${ }^{2}$ Significance levels determined by F test based on the single-factor ANOVA for each pairwise comparison of a quantitative trait and marker locus yPercentage of phenotypic variation explained by the marker locus based on single-factor ANOVA analysis of marker-trait association.

'Unassigned marker.

their role in the development of vegetable crops. In: D.M. Bates, R.W. Robinson, and C. Jeffrey (eds.). Biology and utilization of the Cucurbitaceae. Comstock Publishing, Ithaca, N.Y.

Chambliss, O.L., H.T. Erickson, and C.M. Jones. 1968. Genetic control of bitterness in watermelon fruits. Proc. Amer. Soc. Hort. Sci. 93:539-546.

Danin-Poleg, Y., N. Reis, G. Tzuri, and N. Katzir. 1998. Simple sequence repeats as reference points in Cucumis mapping, p. 349-353. In: J.D. McCreight (ed.). Cucurbitaceae. ASHS Press, Alexandria, Va.

Dijkhuizen, A. and J.E. Staub. 1999. QTL conditioning yield and fruit quality traits in cucumber (Cucumis sativus L.). Cucurbit Gen. Coop. Rpt. 22:8-10.

Edwards, M.D., C.W. Stuber, and J.F. Wendel. 1987. Molecular-marker facilitated investigations of quantitative-trait loci in maize. I. Num- bers, genomic distribution and types of gene action. Genetics 116:113-125.

El-Hafez, A.A.A., A.K. Gaafer, and A.M.M. Allam. 1981. Inheritance of flesh colour, seed coat cracks and total soluble solids in watermelon and their genetic relations. Acta Agron. Acad. Hungaricae 30:82-86.

El-Hafez, A.A.A., A.K. Gaafer, and A.M.M. Allam. 1985. Inheritance of flesh colour, seed coat crack and total soluble solids and their genetic relations. II. Quantitative characters and the association between various characters. Acta Agron. Acad. Hungaricae 34:84-89.

Hashizume, T., T. Sato, and M. Hikai. 1993. Determination of genetic purity of hybrid seed in watermelon (Citrullus lanatus) and tomato (Lycopersicon esculentum) using random amplified polymorphic DNA (RAPD). Jap. J. Breed. 43:367-375.

Hashizume, T., I. Shimamoto, Y. Harushima, M.
Yui, T. Sato, T. Imai, and M. Hirai. 1996. Construction of a linkage map for watermelon (Citrullus lanatus (Thunb.) Matsum \& Nakai) using random amplified polymorphic DNA (RAPD). Euphytica 90:265-273.

Hawkins, L.K., F. Dane, T.L. Kubisiak, B. Rhodes, and R. Jarret. 2001. Linkage mapping in a watermelon population segregating for fusarium wilt resistance. J. Amer. Soc. Hort. Sci. 126:344-350.

Henderson, W.R. 1989. Inheritance of orange flesh color in watermelon. Cucurbit Gen. Coop. Rpt 12:59-63.

Henderson, W.R., G.H. Scott, and T.C. Wehner. 1998. Interaction of flesh color genes in watermelon. J. Hered. 89:50-53.

Jung, G., D.P. Coyne, P.W. Skroch, J. Nienhuis, E. Arnaud-Santana, J. Bokoski, H.M. Ariyarthne, J.R. Steadman, J.S. Beaver, S.M. Kaeppler. 1996. Molecular markers associated with plant architecture and resistance to common blight, web blight, and rust in common beans. J. Amer. Soc. Hort. Sci. 121:794-803.

Kaga, A., M. Ohnishi, T. Ishii, and O. Kamijima. 1996. A genetic linkage map of azuki bean constructed with molecular and morphological markers using an interspecific population (Vigna angularis $\times$ V. nakashimae). Theor. Appl. Genet. 93:658-663.

Kanda, T. 1931. The inheritance of seed-coat colouring in the watermelon. Jap. J. Genet. 7:30-38.

Kennard, W.C., K. Poetter, A. Dijkhuizen, V. Meglic, J.E. Staub, and M.J. Havey. 1994. Linkages among RFLP, RAPD, isozyme, disease-resistance, and morphological markers in narrow and wide crosses of cucumber. Theor. Appl. Genet. 89:42-48.

Kubisiak, T.L., F.V. Hebard, C.D. Nelson, J. Zhang, R. Bernatzky, H. Huang, S.L. Anagnostakis, and R.L. Doudrick. 1997. Molecular mapping of resistance to blight in an interspecific cross in the genus Castanea. Phytopathology 87:751-759.

Kwon, Y.S. and F. Dane. 1999. Inheritance of light green flower color $(g f)$ in watermelon (Citrullus lanatus). Cucurbit Gen. Coop. Rpt. 22:31-33.

Lee, S.J., J.S. Shin, K.W. Park, and Y.P. Hong. 1996. Detection of genetic diversity using RAPD-PCR and sugar analysis in watermelon (Citrullus lanatus (Thunb. Mansf.) germplasm. Theor. Appl. Genet. 92:719-725

Liu, B.-H., 1997. Statistical genomics: Linkage, mapping and QTL analysis. CRC Press, N.Y.

Martyn, R.D. and D. Netzer. 1991. Resistance to races 0,1 , and 2 of Fusarium wilt of watermelon in Citrullus sp. PI-296341-FR. HortScience 26:429-432.

Meglic, V. and J.E. Staub. 1996. Inheritance and linkage relationships of isozyme and morphological loci in cucumber (Cucumis sativus L.). Theor. Appl. Genet. 92:865-872.

Navot, N., M. Sarfatti, and D. Zamir. 1990. Linkage relationships of genes affecting bitterness and flesh color in watermelon. J. Hered. 81:162165

Oliver, M., J. García-Mas, A.I. López, H. GómezPaniagua, and M. Carmen de Vicente. 1998. Toward a sturdy genetic map of melon (Cucumis melo L.), p. 362-364. In: J.E. McCreight (ed.). Cucurbitaceae. ASHS Press, Alexandria, Va.

Perin, C., L. Hagen, C. Dogimont, V. De Conto, and M. Pitrat. 1998. Construction of genetic map of melon with molecular markers and horticultural traits, p. 370-376. In: J.D. McCreight (ed), Cucurbitaceae. ASHS Press, Alexandria, Va.

Poole, C.F. 1944. Genetics of cultivated cucurbits. J. Hered. 35:122-128.

Poole, C.F. 1945. Interaction of sex, shape, and 


\section{Breeding, Cultivars, Rootstocks, \& Germplasm Resources}

weight genes in watermelon. J. Agr. Res. 71:533-553.

Poole, C.F., P.C. Grimball, and D.R. Porter. 1941. Inheritance of seed characters in watermelon. J. Agr. Res. 63:433-457.

Porter, D.R. 1937. Inheritance of certain fruit and seed characters in watermelons. Hilgardia 10:489-509.

Robinson, R.W. and D.S. Decker-Walters. 1997. Cucurbits. CAB International, New York.

SAS Institute. 1996. SAS system for Windows.
SAS Institute, Cary, N.C.

Shimotsuma, M. 1963. Cytogenetical studies in the genus Citrullus. VII. Inheritance of several characters in watermelon. Jap. J. Breed. 13:235-240

Staub, J.E., F.C. Serquen, and M. Gupta. 1996. Genetic markers, map construction, and their application in plant breeding. HortScience 31:729-741.

Wagner, D.B., G.R. Furnier, M. Sahai-Maroof, S.M. Williams, B.P. Danick, and R.W. Allard. 1987. Chloroplast DNA polymorphisms in lodgepole and jack pines and their hybrids. Proc. Natl. Acad. Sci. 84:2097-2100.

Weetman, L.M. 1937. Inheritance and correlation of shape, size and color in watermelon (Citrullus lanatus Schrad.) Iowa Agr. Expt. Sta. Res. Bull. 228:222-256.

Zhang, X.P., and B.B. Rhodes. 1993. Inheritance of resistance to races 0,1 and 2 of Fusarium oxysporum f. sp.niveum in watermelon (Citrullus sp. PI 296341). Cucurbit Gen. Coop. Rpt. 16:77-78. 